Relations industrielles

Industrial Relations

\title{
Automation and Economic Progress, par Howard R. Bowen et Garth L. Mangum, Prentice-Hall Inc., Englewood Cliffs, N.J., 1966, 170 pages.
}

\section{Jean Sexton}

Volume 22, numéro 3, 1967

URI : https://id.erudit.org/iderudit/027825ar

DOI : https://doi.org/10.7202/027825ar

Aller au sommaire du numéro

Éditeur(s)

Département des relations industrielles de l'Université Laval

ISSN

0034-379X (imprimé)

1703-8138 (numérique)

Découvrir la revue

Citer ce compte rendu

Sexton, J. (1967). Compte rendu de [Automation and Economic Progress, par Howard R. Bowen et Garth L. Mangum, Prentice-Hall Inc., Englewood Cliffs, N.J., 1966, 170 pages.] Relations industrielles / Industrial Relations, 22(3),

454-454. https://doi.org/10.7202/027825ar

Tous droits réservés @ Département des relations industrielles de l'Université Laval, 1967
Ce document est protégé par la loi sur le droit d'auteur. L’utilisation des services d'Érudit (y compris la reproduction) est assujettie à sa politique d'utilisation que vous pouvez consulter en ligne.

https://apropos.erudit.org/fr/usagers/politique-dutilisation/ 
These recommendations received widespread publicity and obscured other features. The report, as a whole, which is a most comprehensive survey of the contemporary economic, business and social structure in the United States.

An important point made is that outomation or technological innovation cannot be adjudged the sole culprit in the displacement of lobor on the cause of unemployment.

All the other contributing foctors ore set forth, reinforced by statistical moterials and illustrotive examples.

The report transcends what is ordinarily conceived of as problems arising out of outomation. It really amounts to a blueprint for the minimization or cbolition of unemployment.

The book is recommended as perhaps most balonced presentation of the problems present in this technological age and a serious attempt to offer o satisfactory solution.

Whether universal agreement can be accorded its recommendotions is to be doubted. Yet one's one differing plan to cope with and offer a solution to the serious problems considered, could be subjected to similar criticism. The issues involved are most assuredly perplexing

\section{Benjamin S. KIRSH}

Automation and Economic Progress, par Howard R. Bowen et Garth L. Mangum, Prentice-Hall Inc., Englewood Cliffs, N.J., 1966, 170 pages.

Automation and Economic Progress est un lésumé du rapport de la commission nationale sur lo technologie, l'automation et le progrès économique. Les auteurs, tous deux membres de la dite commission, ont choisi judicieusement parmi toutes les études faites pour cette dernière, dix ropports qui leur ont cidé à bâtir ce livre. Nous pouvons civiser cet ouvrage en quatre grandes parties.

Les outeurs débutent par des considérations d'ordre général à sovoir la vitesse du changement technologique (Chap. 1) et so corrélation avec le chômage (Chop. 2).

Dans un second temps Bowen et Mangum cherchent une solution pour éviter la résis- tance ou changement. Pour ce faire, its proposent de créer un climat favoroble à l'adaptation ou changement technologique par un niveau d'emploi et un revenu suffisont (Chop. 3). Mais il ne suffit pas de créer un climat. Des politiques publiques (Chap. 4) et privées (Chap. 5) adéquates sont indispensables pour faciliter l'adaptation à ce chongement technologique.

Dans une troisième partie, les auteurs font quelques considérations générales sur la technologie et les besoins non sotisfaits des hommes et de la communouté (Chap. 6). Bowen et Mangum considèrent la technologie par ropport aux besoins de la communauté (Chop. 7) et par rapport ou milieu de trovail (Chop. 8).

Finalement, les auteurs font un chapitre spécial pour résumer leurs conclusions et leurs recommandations principoles. (chap. 10)

Tout le reste du livre est consocré ò l'exposé intégral de quatre études supplémentaires qui ont été foites pour la $<\mathrm{No}$ tionol Commission on Technology, Automation and Economic Progress》

En résumé, disons que l'utilité principole de ce livre est de démystifier le mot «AUTOMATION» et de démontrer qu'on peut s'en servir d'une forcon très rotionnelle ò certoines condition:s.

\section{Jean SEXTON}

\section{Modern Economic Growth, Rate, Structure and Spread, Simon Kuznets, New Haven and London Yole University Press, 1966, 529 pages.}

In a comprehensive onalysis of the quantitative characteristics of economic growth, $\mathrm{Mr}$. Kuznets illuminates the basic features of the modern economic epoch. He makes $c$ detailled comparative onclysis of industrial structure, income distribution among factors and by size, trends in patterns of product use, and growing international interdependance in the modern period.

The economic world no longer revolves cbout London and New York. Dozens of new nations are struggling toward economic independence and industrial growth under institutional arrangements quite unlike those of the West. That is why a najor portion of the book is devoted to an investigation of international diversity and the underdeveloped countries. 